\title{
Integration and Development of Employability Skills into Malaysian Higher Education Context: Review of the Literature
}

\author{
Mehrnaz Fahimirad ${ }^{1}$, Professor Dr Pradeep Kumar Nair ${ }^{2}$, Sedigheh Shakib Kotamjani ${ }^{3}$, \\ Maryam Mahdinezhad ${ }^{4} \&$ Jia Bao Feng ${ }^{5}$ \\ 1 Postdoctoral Fellowship, School of Hospitality, Tourism and Events, Faculty of Social Sciences \& Leisure \\ Management, Taylor's University Malaysia \\ ${ }^{2}$ Deputy Vice-Chancellor, Taylor's University Malaysia \\ ${ }^{3}$ Department of Language Education \& Humanities; Universiti Putra Malaysia \\ 4 Department of Educational Management, Faculty of Management and Economics, Sultan Idris Education \\ University, Malaysia \\ ${ }^{5}$ Faculty of Human Development, Sultan Idris University, Malaysia \\ Correspondence: Mehrnaz Fahimirad, Postdoctoral Fellowship, School of Hospitality, Tourism and Events, Faculty \\ of Social Sciences \& Leisure Management, Taylor's University Malaysia. \\ E-mail: Mehrnaz.Fahimirad@taylors.edu.my
}

Received: August 12, 2019

Accepted: September 17, 2019

Online Published: September 19, 2019

doi:10.5430/ijhe.v8n6p26

URL: https://doi.org/10.5430/ijhe.v8n6p26

\begin{abstract}
This paper aims to provide a comprehensive literature review on the role of employability skills or generic skills in designing, integrating, and assessing curriculum in Malaysian higher education context. This study addresses the issue and challenges of integrating generic skills or employability skills in higher education context. Then the research gap on the lack of integrating generic skills in Malaysian higher education system is highlighted and the past studies which addressed the issue of integrating and assessing generic skills in Malaysian universities are reviewed. The results revealed that some Malaysian universities attempted to integrate generic skills into their curriculum to increase the rate of employability; however, there is an ambiguity regarding the assessment of generic skills in the context of higher education. Further research needs be conducted to investigate the assessment of generic skills.
\end{abstract}

Keywords: job skills, curriculum development, higher educations, employability skills, generic skills, Malaysia

\section{Introduction}

The nature of curriculum refers to divers range of issues such as practical course, process, syllabus, product, and praxis (Kelly \& Carbonaro, 2012). Curriculum as a product highlights education. Curriculum designers set objectives, draw up a plan and measure the outcomes (Kridel \& Kridel, 2012). The idea of the curriculum, its implementation in teaching-learning methods, learning engagement, and students' autobiographical experience have been negotiated in an interactive process. In this respect, curriculum as the process approach is developed based on the informed and committed actions (Grundy, 2006). Curriculum needs a continuous assessment of what needs to be modified and what is considered valuable in order to be developed via interaction between a dynamic action and contemplation.

In the context of higher education, the curriculum design is highly affected by the social, economic, physical, and cultural environment. Practical curriculum designers are supposed to identify students' and society's needs to develop a new curriculum. However, recently there is a critical scarcity in the number of effective curriculums since the finalized curriculums found to be insufficient; led to less participation in the industry training programs. In recent years, the higher education has encountered unmatched disruption since top companies clearly assert that curriculum designers, design, deliver, and assess degree qualifications in traditional ways. Graduate students fail to perform well in the real world. In 20-year time, approximately half of current jobs are more likely to be high-tech whereas $65 \%$ of school children will be hired in jobs which have not existed yet (Yaacob, 2012). Certainly, most future jobs require high social skills, because recent economy generates wealth via creativity and consequently creativity is effectively fostered through collaboration (Larson \& Miller, 2011). Due to the importance of social skills 
and creativity, universities are supposed to align their curriculum design constructively to fulfill the future workforce capabilities and to ensure continuous success. A future-ready curriculum requires to emphasize skills and abilities which are necessary across diverse jobs and work settings (Mohd* et al., 2013).

In 2016, World Economic Forum's Future of Jobs reported that complexity of skills will be increasing and advanced skills are required for graduates. Based on the World Economic Forum (WEF) most critical 21st century skills are classified into three categories: Competencies, Foundational Literacies, and Character Qualities. Over the past two decades, many scholars have extensively discussed the application and assessment of competences in context of higher education. Competencies are defined as constructs, which expressed in behavior in a particular context. Competences are defined as an integration of knowledge, skills and attitudes which are aligned to a professional context (Kelder \& Walls, 2017). In what follows, the controversy on core competencies in higher education curricula is discussed. The opponents of competency based education in higher education curriculum express that this curriculum is excessively prescriptive and skill-oriented; hence, this competency-based curriculum is unfavorable to the academic context of higher education. Moreover, it has been reported that many higher education universities in developing countries are experiencing a wide gap between the needs of societies and their curricula. Hence, these curricula lack high skills or competencies in problem solving, project management and team working (van den Akker, 2007). Based on the previous studies, competences are more likely to develop in five levels in the Structure of Observed Learning Outcomes: pre-structural, uni-structural, multi-structural, relational and extended abstract. In the higher level of leaning, students can construct a logic and generalise those meanings to other contexts (Azmi, Hashim, \& Yusoff, 2018). A requirement for reaching these higher level of learning is deep learning (Dow, Heslin, \& Mealey, 2014). In this level, students achieve a particular level to select competences to achieve the intended learning outcomes (Barrie, 2012). Therefore, competences and learning outcomes are interrelated concepts.

In higher education context, the problem of 'key skills' pose the challenge to planning curriculum to serve a more diverse student groups. Primarily based on the Malaysia's experience, this paper aims to review the integration and implementation of employability skills or generic skills in different curriculum designs in higher education context. Thus, the curriculum designers recognized the necessity for transforming curriculum in higher education to assist student's success in their future careers. Moreover, this study aims to find the gap in the existing literature in terms of generic skills/employability skills to enhance universities' awareness to deliver quality learning more effectively in order to transform into as a world-class university. In the following section, the concept and components of generic skills will be elaborated and reviewed.

\section{Defining Employability Skills}

Employability skills are also referred to 'Generic skills', 'generic competencies', 'core skills', and 'underpinning skills'(Mayer, Caruso, \& Salovey, 2016). The word 'skill' is related to values, identity and 'personal attributes'. The generic skills are widely defined as transferable skills which are necessary for employability" and currently the expression of 'generic skills for employability' is extensively used in research and policy (Mohd* et al., 2013).

Based on Mayer's definition (1992) employability skills are the required skills to secure employment and to make a progress within an enterprise in an attempt to contribute effectively to strategic directions and reach one's potential (Salovey, Mayer, Caruso, \& Lopes, 2004)

A variety of skills and personal attributes play roles in individual's employability. Much research has been conducted internationally to define employability, generic skills and key competencies (Mohd* et al., 2013). Several competing definitions have been provided in the existing literature on-Employability skills (Pitman \& Broomhall, 2009). The broadly accepted definition is that employability skills are personal attributes and generic work-related competences which are appreciated by employers (Curtis \& Mcenzie, 2001). Even though some students might be aware of improving generic skills or employability skills through having life experiences outside of university, irrespective of the fact that those experiences would have positive effects on their future career perspectives and development. Hence, the government tends to provide opportunities to improve the generic competencies skills among students through assigning a range of tasks during their academic years.

\section{Generic Skills}

In the process of developing a curriculum, generic skills are used as an umbrella term which refers to various types of generic skills namely time management, teamwork, communication, creativity, problem-solving, and positive attitudes for instance respect, lifelong learning, consideration, and appreciation for students' development (Young \& Chapman, 2010). However, some alumni have ambivalent attitudes towards generic skills because they face uncertain difficulties and practices in key skills (Hughes \& Barrie, 2010). Moreover, university academics and 
teachers are not aware of the development of generic skill issues; therefore, deeper investigations are required to identify the challenges in developing a generic skill (Salovey et al., 2004). Key competences or generic skills are applicable skills across various professional contexts. These generic skills occur in social, occupational, and personal areas (Clarke \& Braun, 2013). In another study, generic skills are summarized by Young and Chapman (2010) based on twelve generic skills frameworks from the USA, Australia, New Zealand, UK, Canada, and Germany. Young and Chapman (2010) maintained that competences of bachelor's degree programmes could not be selected according to the international consensus, due to differences in students' needs and culture; therefore, they managed to identify the most frequently emerging competences such as communication skills, critical reflection, creativity, thinking skills, self-management, leadership, information processing, problem solving, social responsibility, lifelong learning, and teamwork (Young \& Chapman, 2010).Consequently, Young \& Chapman, (2010) emphasized that higher education should develop university students' work-related skills and prepare them for being an effective members of society".Some experts criticize the inclusion of core competency in the higher education curriculum. They pointed out two detriments: One of the detriments of core competency inclusion is that less emphasis is placed on disciplinary knowledge; hence, there is an apprehension that students might not acquire the necessary comprehensible knowledge in their discipline for an academic profession (Azmi, Hashim, \& Yusoff, 2018). Another threat of core competency is that, it is restricted to the achievement of thinking styles, and problem solving associated to a particular profession (Chan, Fong, Luk, \& Ho, 2017). Core competency in education develops different approaches: problem-based learning, project-based education, case-based learning, and dual learning with internships in the real workplace (Schmidt, Loyens, Van Gog, \& Paas, 2007). While, curriculum development is considered as a complicated process that form the 'plan for learning' involving ten interrelated components: rationale, assessment, objectives, learning activities, content, teacher role, location, resources, grouping, and time; hence, if one component changes, it somewhat influences the other components (van den Akker, Fasoglio, \& Mulder, 2010).

The greatest challenge of higher education institutions is to enhance work-related skills and knowledge and generate local graduates more appealing to their employers. Based on the findings from Aliakbari \& Sadeghdaghighi's (2011) studies, employers are more concentrate on soft skills or work-related skills instead of technical competencies (Aliakbari \& Sadeghdaghighi, 2013). The finding revealed that soft skills such as leadership, team working, communication, and entrepreneurial were considered significant for the purpose of employing employees and offering them key positions (Yassin, Abu Hassan, Wan Mohd Amin, \& Amiruddin, 2008). Evers, Rush, and Berdrow (1998) conducted a study to investigate students' competencies for increasing employability. They found that students require developing management of people and tasks, self-management, communications and encouraging innovation and change (Berdrow \& Evers, 1998). In another study carried out by Richens and McClain , 400 employers responded to a survey on their perception of essential work-related skills and competencies for present and prospective employees (Richens \& McClain, 2000). The majority of employers maintained that they require entry-level workers who have employability skills instead of technology competencies. Moreover, $92.6 \%$ of employees regarded the following skills important, namely thinking skills, interpersonal skills, and personal quality competencies (Andrews \& Russell, 2012). As a result, previous studies found most employers are looking for common employability characteristics such as developing management, self-management, interpersonal skills, and thinking skills for employing their staff.

\section{Integrating and Assessing the Generic Skills}

The issue of integrating generic skills into university courses by instructors is the second concern in the course of planning, implementing and assessing the curriculum (Dow et al., 2014). Noticeably, universities have been looking for a change on how to plan, implement and assess a range of generic competencies and how to integrate these skills into the university curricula. To get industries' feedback, researchers could administer surveys to measure and evaluate the influence of integrating generic skills as needed by the industries for continuous development (Shahrin, Toh, Ho, \& Wong, 2002). In the assessment process, the assessor aims to verify whether the student's performance fulfill the standard requirements planned by the standard setting. Standard setting in educational assessments is utilized to make a variety of decisions so as to group test takers according to their performance. Moreover, the process of standard setting conducts quality assessment, either analytical or holistic assessment (Hughes \& Barrie, 2010).

There are two mechanisms for assessing generic skills namely academic-industry, cooperation and variability in the methods of assessment (Hughes \& Barrie, 2010). Mayer (et al., 2001) maintained that it is required to gather a variety of professionals and experts from different industries so as to review assessment criteria for generic skills to meet the employers' needs. The instructors opposed with this statement that lecturers should identify the proper 
mechanism to evaluate student's generic skills development. In what follows, the challenges of integrating generic skills in the context of higher education are discussed.

\section{Higher Education Challenges for Implementing Generic Skills}

Higher education institutions face some challenges for implementing generic skills. The initial challenge of implementation of generic competencies is the lack of identification of significance of these competencies (Yaacob, 2012). Even though,-the majority of universities have integrated generic skills into their mission reports and these competencies are regarded as requirements for graduate students, some higher institutes maintained that provision of generic skills are not required. Almost 20 years later, Mayer, (2012) highlighted that higher education should not be planned only by bringing economic profits to the society, but also higher education should encourage the individual development to assist the achievement of work-related skills and improving the society (Mayer et al., 2016). The second challenge is related to lack of integration of generic skills into curriculum planning and alignments; the third challenge is associated with scarcity of providing professional development to academics (Chan et al., 2017). The significance of generic competencies frequently is realized by students after they graduate from university. Moreover, employers regard generic skills highly important because those skills have work-related nature. Reliable assessment enables employers to get concrete information about students' employability and work-related skills. For the purpose of employment in government sectors, they have some expectations in terms of developing generic skills. The graduates should prove the evidence to develop those competencies so as to turn them into socially good citizens (Hughes \& Barrie, 2010). The question raised here is that whether the assessments of generic skills are required to be evaluated and acknowledged. Based on Chapman \& O'Neill (2010), teachers are required to contemplate on the assessment of generic skills (Chapman \& Neill, 2010).

\section{The Malaysian University System and Curriculum}

The Ministry of Higher Education was founded in 2004. The departments of Higher Education Management Department (JPIPT) is divided into IPTA for managing public universities and the IPTS for managing private universities. In 2007, the Malaysian Qualifications Agency (MQA) was founded to improve the academic quality in universities. The MQA is considered as the reference and the basis of quality assurance with the aim of implementing the Malaysian Qualification Framework to highlight the standards for national qualification and ensure the quality of higher education. MQF is developed and classified based on a collection of nationally approved benchmarks and criteria against international best practices. Moreover, MQF explains the learning outcomes in different areas of study, determines deserved academic levels, and credit system consistent with student academic load. Recognized higher education sources approved and accepted those criteria for awarding qualifications. Furthermore, MQF has laid great emphasis on learning outcomes in different majors such as knowledge, social skills \& responsibility, psychomotor/technical skills, values, ethics, professionalism, attitudes, team skills and communication, critical thinking, lifelong learning, scientific approach, managerial \& entrepreneurial skills, and information management.

Despite the fact that MQF focused on the aforementioned criteria in implementing curricula, experts have realized that jobless Malaysian graduates are not sufficiently prepared with the required skills based on employers' expectation. Unemployed Malaysian graduate lack sufficient skills in problem-solving skills, English language proficiency, as well as lack of professional manners. Hence, one of the concerns of parliamentarians is the public unemployment among Malaysian graduates. HRM ASIA (2012) informs that each year, 150,000 people graduate from Malaysian universities; however, many of those graduates are not successful to secure a job.

This finding was supported by Khalid, Abd Hamid, \& Sailin, (2014) who mentioned that in December 2012, Malaysia had very low rate of unemployment of 3.3\% (434,000 of its 13-million labor force); however, the rate of graduate unemployment was quite high (Khalid, Abd Hamid, \& Sailin, 2014). Prior literature has shown that the high rate of graduate unemployment could be attributed to a mismatch of talent in Malaysian higher institutions; moreover, ineffective delivery system plays a major role in the rate of unemployment. Hence, the government took initiatives to assist graduates to find jobs through establishing the government agency named as the Graduate Career Accelerated Program (GCAP). In accordance with Ministry of Higher Education of Malaysia, generic competencies are the most important skills in the job market, particularly in this fast emerging world of technology (Larson \& Miller, 2011). Based on the results of past studies on generic skills, the soft skills elements developed by the Malaysian Ministry of Higher Education in 2007 and were introduced to the public universities. Datuk Mustafa Mohamed, the previous minister of higher education, mentioned that the module of generic skills or soft skills were included in the curriculum after taking into account employers' complaints about local graduates' soft skills. Moreover, to address this issue, the Malaysian government developed and implemented the new curriculum plan to provide high quality 
outcomes in graduate levels through concentrating on global careers. Moreover, universities are making attempt to find ways to develop and to assess critical skills in their students.

\section{Methods}

In this study, 23 articles which investigated curriculum and generic skills in the context of Malaysian higher education were selected from digital library databases. The researchers employed the search criteria that the articles must be published recently from 2005 to 2018 and the term 'curriculum' and 'generic competency' should be existed in the title and the keywords. For doing systematic literature review on curriculum and generic competencies, the articles were systematically assessed during two months and our attentions were focused on the ideas and discussion on the notion of integrating generic skills into higher education curriculum. The articles were analyzed in two phases. Firstly, the existing gap in the literature regarding the lack of generic skills in universities were identified, then the concept of generic skills is defined and challenges of integrating those skills in curriculum design and alignment are investigated. Secondly, the researcher raised the issue related to the Malaysian curriculum design and lack of integration of generic skills in higher education, it is followed by reviewing the studies that developed and integrated generic skills into Malaysian higher education systems (Clifford \& Montgomery, 2015).

\section{Integrating Generic Skills into Malaysian Higher Education Institutions}

Incorporating generic skills into higher education curricular is considered as a challenging task (Yaacob, 2012). In what follows, the studies carried out to integrate generic competencies in Malaysian higher educational context were reviewed. The Universiti Malaysia Terengganu (UMT) redesigned the graduate curriculum by integrating and implementing generic skills to enhance the employability of students (Yassin et al., 2008). Altbach, Reisberg, \& Rumbley, (2010) investigated and examined the challenges of integrating, implementing and assessing this new curriculum which integrated the components of generic skill competencies into UMT (Altbach, Reisberg, \& Rumbley, 2010). The structure of curriculum in UMT is developed based on three-stage of Ritz's Model. In 2004, UMT revised its curriculum, in each program, the emphasis was given on integrating and implementing generic skills in all courses. UTM identified the components of generic skills based on the reports of the national unemployment and findings of past studies in different universities. They integrated following skills: communication, technology (ICT), analytical thinking, learning to learn, languages, information communication, entrepreneurship, numerical competency, and character building into the curriculum. Public Universities of Malaysia documented the importance of these competencies in the Code of Practice for Quality Assurance which assess the graduates' ability to take their responsibilities and roles (Md. Yunus et al., 2006).

Moreover, UMT enriched students' campus knowledge through including various co-curriculum activities to develop their social network and skills. Hence, the co-curriculum activities were included to enhance generic skills, generate holistic, and versatile graduates either directly or indirectly. Generally speaking, they integrated and trained organizational skills, developed spirit of cooperation and teamwork, leadership, and staff discipline. Furthermore, they provided students with opportunities to discover their talents. Therefore, UMT offered different co-curriculum courses or value added competencies including sport and martial-arts activities, industrial training, cultural, and leadership activities (Yunus, 2001). Moreover, this holistic curriculum framework is designed to increase, soft skills \& emotional spiritual quotient, and content skills based on industrial-training, and real knowledge through connecting with community with a range of proper professional attitudes.

This holistic framework equips graduate students with a set of skills which assist them to be productive members to succeed in a wide range of responsibilities and tasks. It should be taken into account that these attributes should be practiced professionally through professional development programs to enable students to integrate the required skills and knowledge. The incorporation of generic skills through both curriculum and co-curriculum programs particularly in the united club and leadership activities provided students with value added competencies and sustainable employment of graduates.

However, Yasin \& Liu, (2016) mentioned that the success of this curriculum is significantly dependent on the commitment, supervision, monitoring, and the accessibility of the appropriate infrastructure. In another study, (Yasin \& Liu, 2016) highlighted that issues related to integrating generic skills into higher education curricular such as Universiti Kebangsaan Malaysia (UKM) and other public universities in Malaysia is not related only to the planning, implementing, and assessing phases but also the issues related to logistical problems. Besides, students and lecturers lack the existing resources to apply generic skills that they are going to learn and teach (Shahrin et al., 2002). 
A study conducted by (Yaacob, 2012) investigated students' and lecturers' perspective on integrating generic skills into compulsory courses in Universiti Kebangsaan Malaysia (UKM). Compulsory courses were Islamic and Asian Civilizations (TITAS and Ethnic Relation). Moreover, the issues related to integration of generic skills such as operational context, integration ability, and assessment mechanism were measured. Yaacob (2012) aimed to identify whether generic skills were 'naturally occurring' within the current course programs, and whether any methods can be developed to record and assess explicitly those competencies. He also examined to what extent individual lecturers can integrate these competencies into the courses throughout the planning, implementing, and assessing phases. Moreover, Yaacob (2012) aimed to examine the proper operational context in which the generic skills are expected to develop and investigate the proper instrument to evaluate students' development in generic skills. The researcher distributed a survey among 2,500 students and 22 lecturers who taught compulsory courses. To compare the lecturers' and students' perspective towards integration of generic skills, frequency analysis was employed (Yacob, Kadir, Zainudin, \& Zurairah, 2012).

The findings revealed that both lecturers and students approved the methods of recording generic skills and developing assessment of generic skills. Though, lecturers maintained that integrating generic skills are less likely to be incorporated into compulsory courses and those competencies are not 'naturally occurring' within the current courses. Besides, they believe that UKM not appropriately provided operational context for developing generic skills. They opposed to the statement that lecturers can identify the appropriate mechanism to evaluate student's generic skills. Contrary to the lecturers' viewpoint, students had strong attitude towards integrating generic skills into compulsory courses.

In another study (Nair \& Fahimirad, 2019), Pradeep Kumar Nair Deputy Vice-Chancellor reported that Taylor's University recognized the need to change its curriculum framework. Taylor's University has introduced a New Curriculum Framework (NCF) in terms of design, delivery, assessment and outcomes to address the emerging challenges in higher education and more effectively engage and educate the millennial and post millennial generation of learners. The NCF will integrate the essential employability skills into Taylor's degree programs to assist students to succeed in the emerging global landscape. This is to meet growing demands for a more job-relevant curriculum and a work-ready, resilient and intentional graduate via the balanced and wholesome "integration of science and arts" into the curriculum (incorporated via nurturing both hemispheres of the brain). Thus, learners will be equipped with future work skills and abilities required across different jobs and work settings, that is, to develop and showcase the most critical $21^{\text {st }}$ century skills. These will be encapsulated in the revised Taylor's Graduate Capabilities encompassing foundational literacies, competencies and character qualities to support the development of future ready graduates. This university offer the NCF for degree program to enhance the employability of learners by integrating the essential $21^{\text {st }}$ century employability skills into curriculum, being adaptive to changing trends in learning, society, and aligning a constructive curriculum design, delivery, assessment and outcomes. Taylor's University has redesigned its curriculum to fit the learners' future.

The NCF involves significant changes in how the University operates, higher education is delivered, as well as a change in culture and mind-sets. Under the NCF, learning is designed on the basis of personalized learning, immersive and problem-centered, international experience, and outcome-based assessment, entrepreneurial journey, flexible learning, and life skills development, self-management and relationship management. Kumar Nair 2018 (Ali, Zhou, Hussain, Nair, \& Ragavan, 2016) maintained that constructive alignment plays important role in designing and assessing curriculum for teaching and learning to achieve its objectives. Taylor's university developed the following eight principles to design the curriculum: 


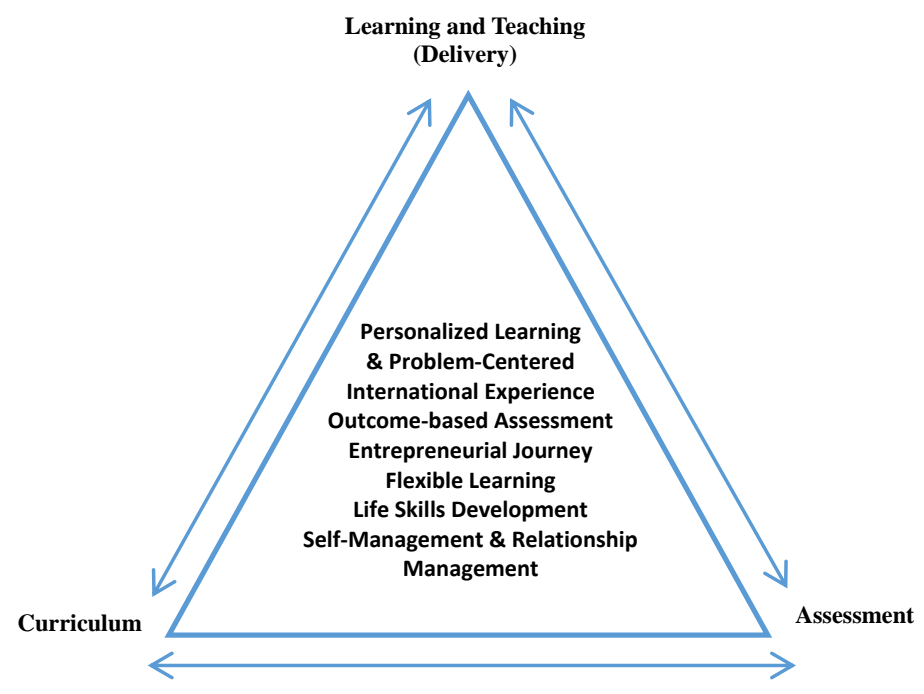

Figure 1. Key parts of SHINE program are now embedded into the curriculum

They intend to improve the following generic capabilities namely discipline specific knowledge, problem solving, critical and creative thinking, problem solving, critical and creative thinking skills, lifelong learning, communication, personal competencies, social competencies, entrepreneurialism, and global perspectives.

\section{Results and Discussion}

In the current digital era, the way people work and do business is strikingly reshaped. Fundamental changes in globalization, technological development, transformation in the nature of work have considerably influenced the demands of workforce. It has been found that many higher education universities in developing countries are experiencing a wide gap between the needs of societies and their curricula. Hence, these curricula lack high skills or competencies in problem solving, project management and team working which refers to generic skills. There are various types of generic skills namely time management, teamwork, communication, creativity, and problem-solving, positive attitudes for instance respect, lifelong learning, consideration, and appreciation for students' development. As stated by Karmel, (2010) generic skills have six frequent components i.e., basic essential skills, personal skills, interpersonal skills, thinking skills, skills which are related to business, and skills associated with community. Limbach \& Waugh, (2014) have supported the importance of integrating generic skills through the curriculum and extra curriculum activities.

The results of the systematic review of literature on challenges of integrating generic skills in higher education revealed that generic skills programs provide work-related skills beyond the disciplinary knowledge. Generic skills have been developed and included in the curricula of higher education in different countries (Cranmer, 2006). However, some academics and instructors do not have awareness and understandings of generic skills development; therefore, deeper investigations are required to identify challenges and obstacles of generic skills agenda in developing counties (Ali et al., 2016).

Moreover, drawing on research of generic skills, there is a strong relationship between the expansion of learners' generic skills and methods of learning and teaching. Therefore, initially the instructors are supposed to make sure that students experience a category of learning experiences; provide opportunities for students' interaction such as peer consultation; develop students' profiles and learning experiences (Pitman \& Broomhall, 2009)

Another finding is related to the challenge of developing, implementing, and assessing of generic skills. Even though, higher education sometimes has embedded generic skills into discipline and curriculum, these skills are seldom assessed as separate learning outcomes (Rosten \& Drummond, 2005), but they are assessed more holistically in the discipline knowledge. Furthermore, students are less likely aware of the development of these competencies in the classes since those capabilities are hidden in curriculum (Hughes \& Barrie, 2010).

Due to various natures of generic skills, the assessment of these skills might not be rated on scales (Hughes \& Barrie, 2010). Another raised question is related to how students are given credits for achieving generic skills (Pitman \& Broomhall, 2009). Furthermore, based on the findings of past studies, it has been revealed that some teachers 
perceived that developing students' generic skills was not their responsibility. Teachers are more likely unwilling to take innovative teaching approaches due to undertaking professional development (Md. Yunus et al., 2006). They maintained that university should take action to develop disciplinary knowledge at high education (Green, Hammer, \& Star, 2009). The finding is consistent with the study conducted in Malaysia by Yaacob, (2012) that lecturers maintained that integrating generic skills are less likely to be incorporated into compulsory courses and those competencies are not 'naturally occurring' within the current courses. Besides, they believe that University Kebangsaan Malaysia has not appropriately provided operational context for developing generic skills. They opposed with the statement that lecturers can identify the appropriate mechanism to evaluate student's generic skills. The reason that teachers are reluctant to apply and assess generic skills is that research and publication are strongly associated with university's reward systems and job promotion; hence, research universities give more priority to research activities than teaching (Rosten \& Drummond, 2005).

The findings indicated that in a study conducted in UMT, the co-curriculum activities were included to enhance generic skills, generate holistic, and versatile graduates to increase the graduates' employability. Therefore, UMT offered different co-curriculum courses or value added competencies including sport and martial-arts activities, industrial training, cultural, and leadership activities. Moreover, this holistic curriculum framework is designed to increase, soft skills \& emotional spiritual quotient, and content skills based on industrial-training, and real knowledge through connecting with community along with a range of proper professional attitudes.

Taylor's University integrated generic skills in its new curriculum framework, and implemented those competencies in vocational courses; however, the assessment of those generic skills has not been investigated. Further study needs to be conducted to investigate lecturers and students' perceptions of integrating generic skills and the assessment of those skills.

\section{Conclusion}

The current review study has presented the challenges of developing and implementing generic skills in the context of higher education institutions in general and Malaysian higher education in particular. The findings indicted that there is a lack of transparency about the concept of generic skills, and a lack of consistent teaching pedagogy on generic skills and assessment criteria. Hence, adequate understanding of generic competencies is required to be developed through establishing a common conceptual base on a generic skills agenda. If a conceptual base is built, the potential challenges of integrating and implementing generic skills could be addressed.

The results of revision revealed that institutional support and commitments should be assigned to increase the awareness of generic competencies and give more value to these skills to affect teachers' and students' perception. Furthermore, implementing generic skills efficiently need enthusiasm and self-motivation of teachers and learners. However, due to lack of time, teachers maintained that they fail to teach generic skills to cover the course subjects at universities.

It should be taken into account that generic skills will develop if students, alumni, and university cooperate and participate fully. Teachers and students perceived that generic competencies play major roles in employability; however, the issue of assessing and giving credit to generic skills has not been thoroughly addressed in the context of higher education. Generic skills need to be assessed as disciplinary knowledge through standardized system. Moreover, employers place a lot of importance on generic skills because these skills considerably manifest work-related skills. Therefore, the results of reliable assessment on generic skills provide employers with comprehensive information and graduate work-readiness. Students often come across to notice the significance of generic skills or work skills after graduating from universities (Chan et al., 2017). It worth mentioning that lecturers should evaluate whether generic skills assessments, assess what are supposed to assess. Future research is definitely required to investigate and develop the appropriate assessment of generic skills to guarantee reliable and consistent interpretation of graduates' work-related competencies outcomes (Strijbos, Engels, \& Struyven, 2015).

The extensive review of literature in Malaysian higher education revealed that generic skills have been integrated into curriculum; however, there is no alignment between teaching pedagogy and students' experience so as to ensure the implementation of a systematic approach to the development of generic skills. Further research should be conducted to identify the best practices of implementing and assessing of generic skills to give teachers' insight and confidence about teaching generic skills. Many research-intensive universities around the world, have come to realize the lack of work-related skills or key competencies among their academicians has deprived their students of being work-ready graduates since the most students are not going to continue working in research sector. Therefore, several universities have hired 'professor of practice' who has great deal of experience and qualifications in industrial sectors in various disciplines to introduce and implement relevant and well-aligned generic skills (Azmi et al., 2018). 
Institutions of higher educations should recognize the significance of developing generic skills and implement those competencies to increase the employability of graduates.

\section{References}

Aida Suraya Muhammad Yunus. (2001). Education reforms in Malaysia. Conference on Educational Research: Understanding Educational Issues in the Asia Pacific Region, 12. https://eric.ed.gov/?id=ED464406

Ali, F., Zhou, Y., Hussain, K., Nair, P. K. \& Ragavan, N. A. (2016). Does higher education service quality effect student satisfaction, image and loyalty? Quality Assurance in Education. https://doi.org/10.1108/QAE-02-2014-0008

Aliakbari, M. \& Sadeghdaghighi, A. (2013). Teachers' Perception of the Barriers to Critical Thinking. Procedia Social and Behavioral Sciences. https://doi.org/10.1016/j.sbspro.2013.01.031

Altbach, P. G., Reisberg, L. \& Rumbley, L. E. (2010). Tracking a Global Academic Revolution. Change: The Magazine of Higher Learning. https://doi.org/10.1080/00091381003590845

Andrews, G. \& Russell, M. (2012). Employability skills development: Strategy, evaluation and impact. Higher Education, Skills and Work-Based Learning. https://doi.org/10.1108/20423891211197721

Azmi, I. A. G., Hashim, R. C. \& Yusoff, Y. M. (2018). The employability skills of Malaysian university students. International Journal of Modern Trends in Social Sciences.

Barrie, S. C. (2012). A research-based approach to generic graduate attributes policy. Higher Education Research and Development. https://doi.org/10.1080/07294360.2012.642842

Berdrow, I. \& Evers, F. T. (2010). Bases of competence: An instrument for self and institutional assessment. Assessment and Evaluation in Higher Education. https://doi.org/10.1080/02602930902862842

Chan, C. K. Y., Fong, E. T. Y., Luk, L. Y. Y. \& Ho, R. (2017). A review of literature on challenges in the development and implementation of generic competencies in higher education curriculum. International Journal of Educational Development, 57(September), 1-10. https://doi.org/10.1016/j.ijedudev.2017.08.010

Chapman, E. \& Neill, M. O. (2010). Defining and Assessing Generic Competencies in Australian Universities: Ongoing Challenges. Education, Research and Perspectives, 37(1), 105-123.

Clarke, V. \& Braun, V. (2013). Teaching thematic analysis: Over- coming challenges and developing strategies for effective learning. The Psychologist. https://doi.org/10.1191/1478088706qp063oa

Clifford, V. \& Montgomery, C. (2015). Transformative Learning Through Internationalization of the Curriculum in Higher Education. Journal of Transformative Education, 13(1), 46-64. https://doi.org/10.1177/1541344614560909

Cranmer, S. (2006). Enhancing graduate employability: Best intentions and mixed outcomes. Studies in Higher Education. https://doi.org/10.1080/03075070600572041

Curtis, D. \& Mcenzie, P. (2001). Employability skills for Australian industry: Literature review and framework development. Report to the Business Council of Australia and the Australian Chamber of Commerce and Industry. https://doi.org/http://hdl.voced.edu.au/10707/40939.

Dow, F., Heslin, J. \& Mealey, E. (2014). Assessment practice for functional employability skills, 9(2003), 70-74.

Green, W., Hammer, S. \& Star, C. (2009). Facing up to the challenge: Why is it so hard to develop graduate attributes? Higher Education Research and Development. https://doi.org/10.1080/07294360802444339

Grundy, T. (2006). Rethinking and reinventing Michael Porter's five forces model. Strategic Change, 15(5), 213-229. https://doi.org/10.1002/jsc.764

Hughes, C. \& Barrie, S. (2010). Influences on the assessment of graduate attributes in higher education. Assessment and Evaluation in Higher Education. https://doi.org/10.1080/02602930903221485

Karmel, T. (2010). Skilling and Reskilling for Our (Greener) Future. Conference Paper. National Centre for Vocational Education Research (NCVER). https://www.ncver.edu.au/

Kelder, J. \& Walls, J. (2017). Research and Development in Higher Education : Curriculum Transformation Volume 40 Curriculum Evaluation and Research Framework: facilitating a teaching team approach to curriculum quality. http://www.herdsa.org.au/research-and-development-...

Kelly, S. \& Carbonaro, W. (2012). Curriculum tracking and teacher expectations: Evidence from discrepant course 
taking models. Social Psychology of Education. https://doi.org/10.1007/s11218-012-9182-6

Khalid, N., Abd Hamid, N. \& Sailin, R. (2014). Importance of Soft Skills for Industrial Training Program: Employers' Perspective. Asian Journal of Social Sciences \& Humanities.

Kridel, C. \& Kridel, C. (2012). Basic Principles of Curriculum and Instruction. In Encyclopedia of Curriculum Studies. https://doi.org/10.4135/9781412958806.n36

Larson, L. C. \& Miller, T. N. (2011). 21st Century Skills: Prepare Students for the Future. Kappa Delta Pi Record. https://doi.org/10.1080/00228958.2011.10516575

Mayer, J. D., Caruso, D. R. \& Salovey, P. (2016). The Ability Model of Emotional Intelligence: Principles and Updates. Emotion Review. https://doi.org/10.1177/1754073916639667

Mayer, J. D., Salovey, P., Caruso, D. R. \& Sitarenios, G. (2001). Emotional Intelligence as a Standard Intelligence. Emotion. https://doi.org/10.1037/1528-3542.1.3.232

Md. Yunus, A. S., Hamzah, R., Ahmad Tarmizi, R., Abu, R., Md. Nor, S., Ismail, H., ... Abu Bakar, K. (2006). Problem solving abilities of Malaysian university students. International Journal of Teaching and Learning in Higher Education. $\quad$ https://link.springer.com/chapter/10.1007/978-94-6300-468-8_7

Mohd, Husain, Y., Mustapha, R., Malik, S. A., Mohamad, S., Rasul, M. S. \& Mokhtar, S. B. (2013). Employability Skills, Co-curriculum Management, Peer Interaction and Contextual Teaching and Learning in Technical Institutions. (March), 23-24.

Nair, P. K. \& Fahimirad, M. (2019). A Qualitative Research Study on the Importance of Life Skills on Undergraduate Students 'Personal and Social Competencies, 8(5), 71-83. https://doi.org/10.5430/ijhe.v8n5p71

Pitman, T. \& Broomhall, S. (2009). Australian universities, generic skills and lifelong learning. International Journal of Lifelong Education. https://doi.org/10.1080/02601370903031280

Richens, G. P. \& McClain, C. R. (2000). Workplace Basic Skills for the New Millennium. Journal of Adult Education.

Rosten, E. \& Drummond, T. (2005). Fusing points and lines for high performance tracking. Proceedings of the IEEE International Conference on Computer Vision. https://doi.org/10.1109/ICCV.2005.104

Salovey, P., Mayer, J. D., Caruso, D. \& Lopes, P. N. (2004). Measuring emotional intelligence as a set of abilities with the Mayer-Salovey-Caruso Emotional Intelligence Test. In Positive psychological assessment: A handbook of models and measures. https://doi.org/10.1037/10612-016

Schmidt, H. G., Loyens, S. M. M., Van Gog, T. \& Paas, F. (2007). Problem-based learning is compatible with human cognitive architecture: Commentary on Kirschner, Sweller, and Clark (2006). Educational Psychologist. https://doi.org/10.1080/00461520701263350

Shahrin, M., Toh, K.-A., Ho, B.-T. \& Wong, J. (2002). Performance assessment: Is creative thinking necessary? [References]. Journal of Creative Behavior. https://doi.org/10.1002/j.2162-6057.2002.tb01057

Strijbos, J., Engels, N. \& Struyven, K. (2015). Criteria and standards of generic competences at bachelor degree level: A review study. Educational Research Review, 14, 18-32. https://doi.org/10.1016/j.edurev.2015.01.001

van den Akker, J. (2007). Curriculum Design Research. In An Introduction to Educational Design Research. https://doi.org/10.21839/jaar.2018.v3iS1.156

van den Akker, J., Fasoglio, D. \& Mulder, H. (2010). A curriculum perspective on plurilingual education. Guide for the Development and Implementation of Curricula for Plurilingual and Intercultural Education. https://rm.coe.int/16805a1e57

Yaacob, M. (2012). Integrating generic competencies ( GCs) into University 's compulsory courses : perspectives of lecturers and students, 59, 574-583. https://doi.org/10.1016/j.sbspro.2012.09.316

Yacob, A., Kadir, A. Z. A., Zainudin, O. \& Zurairah, A. (2012). Student Awareness Towards E-Learning In Education. Procedia - Social and Behavioral Sciences. https://doi.org/10.1016/j.sbspro.2012.11.310

Yassin, S., Abu Hassan, F., Wan Mohd Amin, W. A. A. \& Amiruddin, N. A. (2008). Implementation of Generic Skills in the Curriculum. EDU-COM 2008 International Conference. https://ro.ecu.edu.au/ceducom/54/

Young, J. \& Chapman, E. (2010). Generic Competency Frameworks: A Brief Historical Overview. Education Research and Perspectives. https://eric.ed.gov/?id=EJ945700 